\title{
SIMULASI KEBIJAKAN TARIF IMPOR JAGUNG TERHADAP KINERJA EKONOMI JAGUNG DI INDONESIA
}

\section{THE SIMULATION OF CORN IMPORT TARIF POLICY TOWARD THE PRODUCTIVITY OF CORN ECONOMY IN INDONESIA}

\author{
Vioryza Balgies Pangestika ${ }^{1 *}$, Syafrial $^{2}$, Suhartini $^{3}$ \\ ${ }^{I}$ Pascasarjana Program Studi Ekonomi Pertanian, Fakultas Pertanian, Universitas Brawijaya \\ ${ }^{2,3}$ Jurusan Sosial Ekonomi, Fakultas Pertanian, Universitas Brawijaya \\ Jl. Veteran Malang 65145, Jawa Timur, Indonesia.
}

Received: 3rd November 2015; Revised: 28th Desember 2015; Accepted: 4th January 2016

\begin{abstract}
ABSTRAK
Tujuan dari penelitian ini adalah untuk menganalisis sejauh mana kebijakan tarif impor mempengaruhi kinerja ekonomi jagung di Indonesia. Kinerja ekonomi jagung yang dimaksud dalam penelitian ini meliputi permintaan dan penawaran jagung domestik, harga jagung domestik, impor jagung Indonesia, produktivitas jagung serta luas areal jagung. Metode analisis yang digunakan adalah fungsi produksi serta fungsi permintaan dan penawaran dalam bentuk persamaan simultan. Hasil analisis menunjukkan bahwa penghapusan tarif impor jagung Indonesia dapat meningkatkan permintaan dan impor jagung Indonesia.Sedangkan hasil simulasi perubahan tarif sebesar 5\% dan $10 \%$ menyebabkan peningkatan harga jagung domestik serta meningkatkan penawaran jagung Indonesia. Berdasarkan hasil simulasi dapat disimpulkan guna mengurangi impor jagung Indonesia maka diharapkan tarif impor jagung tetap dipertahankan.
\end{abstract}

Kata Kunci: Impor; jagung; kinerja ekonomi jagung; tarif impor

\begin{abstract}
The objective of this research is to analyze how far this import tarif policy influences the productivity of corn economy in Indonesia. The method of the analysis used in this research is the production function as well as demand and supply function in a form of simultaneous equation. The result of the analysis shows that the abolition of corn import tarif in Indonesia can raise the demand and corn import in Indonesia. While the simulation results change rate of 5\% and $10 \%$ led to an increase in domestic corn prices as well as increase the supply of corn Indonesia. Based on simulation results concluded, in order to reduce imports of maize Indonesia it is expected that maize import tariffs maintained.
\end{abstract}

Keywords: Import; corn; the productivity of corn economy; tariff of import

\section{Pendahuluan}

Jagung mempunyai peran strategis perekonomian nasional, mengingat fungsinya yang multiguna dimana jagung dapat dimanfaatkan untuk pangan, pakan dan bahan baku industri. Dari seluruh kebutuhan jagung, $50 \%$ diantaranya digunakan untuk pakan ternak. Menurut data Badan Pusat Statistik (BPS) dan Dirjen Tanaman Pangan Kementerian Pertanian

\footnotetext{
${ }^{*}$ Penulis Korespondensi

E-mail: vioryzah@yahoo.com

Telp : +6282231604703
}

(Kementan), produksi jagung nasional tahun 2011 mencapai 17,64 juta ton pipilan kering atau turun 684,39 ribu ton dibandingkan tahun 2010. Penurunan produksi terjadi di Jawa sebesar 477,29 ribu ton dan di luar Jawa sebesar 207,10 ribu ton (BPS, 2012).

Menurut Timor (2008), terdapat dua kondisi yang menjadi alasan mengapa suatu negara mengimpor jagung. Kondisi pertama, produksi jagung domestik relatif dapat memenuhi kebutuhan dalam negeri namun pada saat yang sama harga jagung dunia lebih murah dari jagung domestik. Pada kondisi seperti ini konsumen jagung dalam negeri khususnya produsen pakan ternak akan lebih memilih impor jagung 
dibandingkan membeli jagung domestik. Impor jagung oleh perusahaan pakan mendorong harga jagung domestik turun menyamai harga jagung dunia. Hal ini akan memukul produsen jagung domestik, sehingga pemerintah menetapkan tarif tertentu terhadap jagung impor. Kebijakan tarif impor jagung ternyata belum mendorong petani jagung di dalam negeri menjadi lebih efisien.

Kondisi kedua adalah ketika produksi jagung domestik relatif lebih rendah dibandingkan jumlah kebutuhan jagung di dalam negeri. Seperti pada kondisi pertama, misalnya kebutuhan produsen pakan ternak tidak dapat dipenuhi oleh produksi jagung domestik, maka produsen pakan ternak akan memilih mengimpor jagung dari pasar dunia sekalipun harganya lebih mahal. Jika harga jagung dunia lebih mahal maka produsen pakan ternak akan melakukan pengurangan produksi, namun keputusan tersebut juga dipengaruhi oleh rasio harga pakan dan harga hasil peternakan (Timor, 2008).

Tarif merupakan kebijakan perdagangan tertua dan secara tradisional digunakan sebagai sumber penerimaan pemerintah, akan tetapi peranan tarif meluas menjadi alat untuk melindungi industri dalam negeri (Krugman dan Maurice, 1999). Adanya perubahan tarif impor jagung dapat berdampak pada kinerja ekonomi jagung yang meliputi produksi jagung nasional, permintaan jagung, jumlah impor jagung dan harga jagung domestik.

Berdasarkan uraian diatas maka penting dilakukan penelitian tentang simulasi kebijakan tarif impor jagung terhadap kinerja ekonomi jagung di Indonesia. Pentingnya dilakukan simulasi ini guna mengetahui bagaimana dampak dari perubahan tarif impor terhadap kinerja ekonomi Indonesia yang meliputi produksi dan permintaan jagung domestik, harga jagung domestik serta impor jagung Indonesia.

Tujuan dari penelitian ini adalah untuk: 1) Menganalisis faktor-faktor yang mempengaruhi kinerja ekonomi jagung di Indonesia; dan 2) Menganalisis simulasi kebijakan tarif impor jagung terhadap kinerja ekonomi jagung di Indonesia.

\section{Metode Penelitian}

\subsection{Landasan Teori}

Produksi suatu komoditas pertanian (Qj) dalam model agregat merupakan fungsi dari masukan utama lahan (A), modal $(\mathrm{K})$ dan tenaga kerja (L) dan masukan lainnya (Z), yaitu:
$\mathrm{Qj}=\mathrm{f}(\mathrm{A}, \mathrm{K}, \mathrm{L}, \mathrm{Z})$

$\pi=\mathrm{Pj} * \mathrm{f}(\mathrm{A}, \mathrm{K}, \mathrm{L}, \mathrm{Z})-\mathrm{Pa} * \mathrm{~A}-\mathrm{Pk} * \mathrm{~K}-\mathrm{Pl} \mathrm{L}^{*} \mathrm{~L}-\mathrm{Pz} * \mathrm{Z}-$

$\mathrm{Bt}$

Dimana Pj adalah harga komoditi (dalam penelitian ini adalah jagung), Pa harga masukan A, Pk harga masukan K, Pl harga masukan L, Pz harga masukan $\mathrm{Z}$ dan $\mathrm{Bt}$ adalah biaya tetap. Dengan melakukan penurunan secara prosedur matematika, sehingga dari persamaan akan dihasilkan

$\mathrm{NPMi}=\mathrm{Pi}$

Dari persamaan (3) dapat diturunkan fungsi permintaan inputnya, yaitu:

$\mathrm{A}=\mathrm{a}(\mathrm{Pa}, \mathrm{Pj}, \mathrm{Pk}, \mathrm{Pl}, \mathrm{Pz})$

$\mathrm{K}=\mathrm{k}(\mathrm{Pk}, \mathrm{Pa}, \mathrm{Pj}, \mathrm{Pl}, \mathrm{Pz})$

$\mathrm{L}=1(\mathrm{Pl}, \mathrm{Pa}, \mathrm{Pj}, \mathrm{Pk}, \mathrm{Pz})$

$\mathrm{Z}=\mathrm{z}(\mathrm{Pz}, \mathrm{Pa}, \mathrm{Pj}, \mathrm{Pk}, \mathrm{Pl})$

Dengan mensubtitusikan persamaan (4) hingga (7) ke persamaan (1) maka diperoleh persamaan penawaran sebagai berikut:

$\mathrm{Qj}=\mathrm{j}(\mathrm{Pj}, \mathrm{Pa}, \mathrm{Pk}, \mathrm{Pl}$ dan $\mathrm{Pz})$

Produksi padi dipengaruhi oleh luas areal panen dan produktivitas. Faktor-faktor yang mempengaruhi luas areal panen selain harga jagung (Pj) adalah harga bibit (Pbit), harga pupuk (Ppuk), tingkat suku bunga (i) dan harga komoditas lain (Po). Maka fungsi luas areal panen sebagai berikut:

$\mathrm{Lj}=\mathrm{f}(\mathrm{Pj}$, Pbit, Ppuk, I, Po $)$

Sementara itu, faktor-faktor yang mempengaruhi produktivitas jagung adalah harga bibit jagung (Pbit), harga pupuk (Ppuk), tingkat upah (W) dan suku bunga (i). Dengan demikian fungsi produktivitas dapat dituliskan sebagai berikut:

$\mathrm{Yj}=\mathrm{f}($ Pbit, Ppuk, W, i)

Karena itu pula produksi jagung dapat dirumuskan sebagai berikut:

$\mathrm{Qj}=\mathrm{Lj}^{*} \mathrm{Yj}$

Fungsi produktivitas dapat diturunkan dari fungsi produksi sehingga dapat diperoleh fungsi produktivitas dasar (Semaoen, 2011) yang sebagai berikut:

$\mathrm{Q}=\mathrm{f}(\mathrm{A}, \mathrm{L}, \mathrm{C})$

Fungsi penawaran diatas masih tergolong fungsi penawaran statis, padahal dalam kondisi riil penawaran tidak serta merta berubah ketika terjadi perubahan pada faktor-faktor penawaran sehingga diperlukan fungsi penawaran dinamis. Hal ini dilakukan agar mampu menjelaskan kondisi yang terjadi di lapang berdasarkan 
pengaruh time lag yang terjadi. Salah satu model persamaan fungsi dinamis yang banyak dikembangkan adalah Nerlove supply model.

Model luas areal panen jagung dapat dikembangkan dari tiga persamaan sebagai berikut:

$A_{t}^{*}=\alpha_{0}+\alpha_{1} P_{t}^{*}+\alpha_{2} Z_{t}+\varepsilon_{t}$
$P_{t}^{*}=P_{t-1}^{*}+\beta\left(P_{t-1}-P_{t-1}^{*}\right)$.
$A_{t}=A_{t-1}+\gamma\left(A_{t}^{*}-A_{t-1}\right) \ldots$.

$\mathrm{A}_{\mathrm{t}}^{*}$ dan $\mathrm{P}_{\mathrm{t}}^{*}$ tidak dapat dicari nilainya, maka menurut Nerlove (1956) dalam Anindita ${ }^{\mathrm{a}}$ (2008), keduanya dapat dieliminasi dari persamaan. Solusi dari ketiga persamaan diatas menghasilkan:

$\mathrm{A}_{\mathrm{t}}=\alpha_{0} \beta \gamma+\alpha_{1} \beta \gamma \mathrm{P}_{\mathrm{t}-1}+[(1-\beta)+(1-$ $\gamma)] A_{t-1}+[-(1-\beta)(1-\gamma)] A_{t-2}+\alpha_{2} \gamma Z_{t}+$ $(1-\beta) Z_{t-1}+\mu_{t}$

Persamaan (6) diubah ke bentuk reduced form untuk mempermudah estimasi menjadi:

$A_{t}=b_{0}+b_{1} P_{t-1}+b_{2} A_{t-1}+b_{3} A_{t-2}+b_{4} Z_{t}+$ $b_{5} Z_{t-1}+\mu_{t}$

Berdasarkan penjelasan diatas dapat disusun persamaan produktivitas jagung sebagai berikut:

$\mathrm{Y}_{\mathrm{j}}=\mathrm{a}_{0}+\mathrm{a}_{1} \mathrm{~L}_{\mathrm{j}}+\mathrm{a}_{2} \mathrm{P}_{\text {bit }}+\mathrm{a}_{3} \mathrm{P}_{\text {puk }}+\mathrm{a}_{4} \mathrm{~W}+\mathrm{a}_{5} \mathrm{i}$

Pendekatan fungsi dasar dari luas lahan dapat dituliskan sebagai berikut:

$\mathrm{Q}=\mathrm{f}\left(\mathrm{P}_{1}, \mathrm{P}_{2}, \mathrm{P}_{3}, \mathrm{Z}\right)$

Berdasarkan pendekatan fungsi penawaran diatas menunjukkan tingkah laku yang dilakukan oleh petani untuk menentukan luasan lahan yang akan ditanami jagung sehingga dapat disusun fungsi luas lahan berdasarkan tingkah laku atau fungsi biaya sesuai dengan faktor-faktor yang ada pada produksi jagung. harga komoditi itu sendiri ditunjukkan dengan harga jagung, sedangkan untuk harga komoditi lain diwakilkan oleh harga komoditi padi dan harga komoditi kacang tanah dan padi yang juga banyak diusahakan oleh petani. Selain itu, harga input yang digunakan meliputi harga pupuk, harga bibit dan juga tingkat suku bunga yang mewakili modal usaha. Berdasarkan penjelasan tersebut dapat disusun persamaan sebagai berikut:

$\mathrm{L}_{\mathrm{j}}=\mathrm{b}_{0}+\mathrm{b}_{1} \mathrm{P}_{\mathrm{k}}+\mathrm{b}_{2} \mathrm{P}_{\mathrm{p}}+\mathrm{b}_{3} \mathrm{P}_{\mathrm{j}}+\mathrm{b}_{4} \mathrm{i}+\mathrm{b}_{5} \mathrm{P}_{\mathrm{bit}}+\mathrm{b}_{6} \mathrm{P}_{\mathrm{puk}}$

Selain itu, terdapat penawaran jagung yang diperoleh dari penjumlahan produksi jagung domestik dan impor jagung. persamaan tersebut dapat dituliskan sebagai berikut:

$\mathrm{Qs}=\mathrm{Qj}+\mathrm{Mj}$
Penurunan fungsi permintaan didasarkan atas tingkat kepuasan dalam mengkonsumsi barang dan pendapatan yang dibelanjakan dimana konsumen berusaha memaksimumkan kepuasan dengan keterbatasan atau kendala pendapatan.

$\mathrm{U}=\mathrm{f}\left(\mathrm{x}_{1}, \mathrm{x}_{2}, \mathrm{Y}\right)$

Fungsi permintaan diatas tergolong model permintaan statis yang berasumsi bahwa harga akan berubah dari satu keseimbangan menuju keseimbangan yang lain tanpa ada proses penyesuaian harga, padahal pada kondisi riil di lapang yang terjadi tidak seperti itu dikarenakan dibutuhkan penyesuaian secara bertahap oleh harga. Model permintaan dinamis mencakup beberapa model dari yang sederhana hingga yang kompleks. Model yang diadaptasikan dalam penelitian ini adalah partial adjustment model. Partial adjustment model pada dasarnya diturunkan dari persamaan sebagai berikut:

$D_{t}=\alpha_{0}+\alpha_{1} P_{t}+\alpha_{2} Z_{t}+\varepsilon_{t}$

$D-D_{t-1}=\alpha\left(D_{t}^{*}-D_{t-1}\right)$

Nilai $D_{t}^{*}$ tidak dapat diketahui sehingga solusi untuk kedua persamaan diatas menjadi:

$D_{t}=\alpha \alpha_{0}+\alpha \alpha_{1} P_{t}+\alpha \alpha_{2} Z_{t}+(1-\alpha) D_{t-1}$.

Persamaan (15) dapat disederhanakan ke bentuk reduced form menjadi:

$D_{t}=c_{0}+c_{1} P_{t}+c_{2} Z_{t}+c_{3} D_{t-1}+\varepsilon_{t}$

Berdasarkan teori diatas maka fungsi permintaan jagung dapat dituliskan sebagai berikut:

$\mathrm{Qd}=\mathrm{d}_{0}+\mathrm{d}_{1} \mathrm{Pj}+\mathrm{d}_{2}$ Pop $+\mathrm{d}_{3} \ln +\mathrm{d}_{4} \mathrm{Qd}_{\mathrm{t}-\mathrm{I}}$

\subsection{Jenis Data}

Data yang digunakan dalam penelitian ini adalah data sekunder berupa data tahunan dengan rentang waktu (time series) dari tahun 19902010. Sumber data dalam penelitian ini diperoleh dari beberapa instansi terkait, yaitu Badan Pusat Statistik (BPS), FAOSTAT, dan diambil dari situs resmi USDA, situs world Bank, Departemen Pertanian (Deptan) dan berbagai literatur yang menunjang penyusunan penelitian ini. Data yang diambil meliputi penawaran jagung, permintaan jagung, luas areal jagung, harga jagung domestik dan dunia, produktivitas jagung, volume impor jagung, populasi, pendapatan penduduk, tingkat upah, tingkat suku bunga, harga padi, harga kacang tanah, produksi jagung, ekspor dan impor jagung dunia, nilai tukar, HPP, ekspor jagung Amerika Serikat dan Argentina, produksi jagung Amerika Serikat dan Argentina. Selain itu juga diambil data ekspor jagung Indonesia, impor, konsumsi dan stok jagung Jepang serta nilai tukar Jepang terhadap dollar, impor, konsumsi dan stok 
jagung Korea Selatan serta nilai tukar Korea Selatan terhadap dollar.

Dalam penelitian ini, metode analisis data yang digunakan sesuai dengan tujuan Penelitian sebagai berikut.

Tujuan 1. Analisis faktor-faktor yang mempengaruhi kinerja ekonomi jagung di Indonesia.

Faktor-faktor yang mempengaruhi kinerja ekonomi Indonesia yang meliputi produksi, produktivitas, luas areal, permintaan dan penawaran jagung serta impor jagung dianalisis dengan menggunakan fungsi produksi dan fungsi permintaan dalam bentuk persamaan simultan. Spesifikasi model persamaannya adalah sebagai berikut:

\section{Persamaan Penawaran Jagung}

Persamaan penawaran jagung Indonesia terdiri dari beberapa persamaan berikut:

a. Persamaan Produksi Jagung $\mathrm{Qj}=\mathrm{Lj}^{*} \mathrm{Yj}$

b. Persamaan Respon Produktivitas Jagung $\mathrm{Y}_{\mathrm{j}}=\mathrm{a}_{0}+\mathrm{a}_{1} \mathrm{~L}_{\mathrm{j}}+\mathrm{a}_{2} \mathrm{P}_{\text {bit }}+\mathrm{a}_{3} \mathrm{P}_{\text {puk }}+\mathrm{a}_{4} \mathrm{~W}+\mathrm{a}_{5} \mathrm{i}+\mathrm{u}_{1}$

c. Persamaan Respon Luas Areal Jagung

$\mathrm{L}_{\mathrm{j}}=\mathrm{b}_{0}+\mathrm{b}_{1} \mathrm{P}_{\mathrm{k}}+\mathrm{b}_{2} \mathrm{P}_{\mathrm{p}}+\mathrm{b}_{3} \mathrm{P}_{\mathrm{dj}}+\mathrm{b}_{4} \mathrm{i}+\mathrm{b}_{5} \mathrm{P}_{\mathrm{bit}}+\mathrm{b}_{6} \mathrm{P}_{\text {puk }}$ $+\mathrm{u}_{2}$

d. Persamaan Penawaran Jagung Indonesia $\mathrm{Qs}=\mathrm{Qj}+\mathrm{Mj}(31)$

e. Persamaan Impor Jagung di Indonesia $M_{j}=f_{0}+f_{1}\left(P_{w j}-P_{d j}\right)+f_{2} E R+f_{3} Q d+$ $f_{4} M_{j t-1}+u_{3}$

1. Persamaan Permintaan Jagung

Persamaan Permintaan jagung di Indonesia terdiri dari satu persamaan, yaitu:

$\mathrm{Qd}=\mathrm{d}_{0}+\mathrm{d}_{1} \mathrm{P}_{\mathrm{dj}}+\mathrm{d}_{2}$ Pop $+\mathrm{d}_{3} \ln +\mathrm{d}_{4} \mathrm{Qd}_{\mathrm{t}-1}+\mathrm{u}_{4}(33)$

\section{Persamaan Harga Jagung}

Persamaan harga jagung di Indonesia terdiri dari satu persamaan, yaitu:

$$
P_{d j}=e_{0}+e_{1} P_{w}+e_{2} E R+e_{3} N r p+e_{4} H P P+
$$$$
e_{5} P_{d j t-1}+u_{5}
$$

3. Persamaan Ekspor Impor Jagung Dunia

Persamaan ekspor dan impor jagung dunia terdiri dari lima persamaan, yaitu:

a. Persamaan Ekspor Jagung Amerika Serikat $E_{A S}=f_{0}+f_{1} P_{w j t}+f_{2} Q_{j A S t-1}+f_{3} E_{J A S t-1}+$

$u_{6}$ b. Persamaan Ekspor Jagung Argentina $E_{A G}=g_{0}+g_{1} P_{d j t}+g_{2} Q_{j A G t}+g_{3} T W_{t}+u_{7}$

c. Persamaan Total Ekpor Jagung Dunia

$\mathrm{EJW}_{\mathrm{t}}-\mathrm{EJAS}_{\mathrm{t}}+\mathrm{EJAG}_{\mathrm{t}}$

d. Persamaan Impor Jagung Jepang

$M_{j j t}=h_{0}+h_{1} P_{w j t-1}+h_{2} C_{j j t-1}+h_{3}\left(E R J_{t}-\right.$ $\left.E R J_{t-1}\right)+h_{4} S T_{j j t}+u_{8}$

e. Persamaan Impor Jagung Korea Selatan $M_{j k s t}=i_{0}+i_{1} P_{w j t}+i_{2} C_{j k s t}+i_{3} E R K S_{t}+$ $i_{4} S T_{j k s t}+i_{5} T W_{t}+u_{9}$

f. Persamaan Total Impor Jagung Dunia

Impor jagung dunia dibentuk melalui persamaan identitas yang merupakan penjumlahan dari impor jagung negara importir terbesar dunia (Jepang dan Korea Selatan) dan negara Indonesia. Setiap perubahan yang mempengaruhi impor jagung negara-negara importir terbesar dunia mempengaruhi impor jagung dunia. Adapun persamaan total impor jagung dunia sebagai berikut:

$\mathrm{MJW}_{\mathrm{t}}=\mathrm{MJJ}_{\mathrm{t}}+\mathrm{MJKS}_{\mathrm{t}}+\mathrm{MJI}_{\mathrm{t}}$

Dimana:

$\mathrm{MJW}_{\mathrm{t}}=$ =Impor jagung dunia pada tahun $\mathrm{t}$ (ton)

$\mathrm{MJJ}_{\mathrm{t}}=$ Impor jagung Jepang pada tahun $\mathrm{t}$ (ton)

MJKS $_{\mathrm{t}}=$ Impor jagung Korea Selatan pada tahun $\mathrm{t}$ (ton)

$\mathrm{MJI}_{\mathrm{t}}=$ Impor jagung Indonesia pada tahun $\mathrm{t}$ (ton)

g. Persamaan Harga Riil Jagung Dunia

$P_{w j t}=j_{0}+j_{1}\left(E J W_{t}-E J W_{t-1}\right)+$

$j_{2}\left(\frac{\left(M J W_{t}\right.}{M J W_{t-1}}\right)+j_{3} P_{w j t-1}+u_{10}$

Dimana:

$\mathrm{C}_{\mathrm{jjt}-1}=$ Konsumsi jagung Jepang tahun $\mathrm{t}-1$ (ton)

$\mathrm{C}_{\mathrm{jkst}}=$ Konsumsi jagung Korea Selatan tahun $\mathrm{t}$ (ton)

$\mathrm{E}_{\mathrm{AG}}=$ Ekspor Jagung Argentina tahun $\mathrm{t}$ (ton)

$\mathrm{E}_{\mathrm{AS}}=$ Ekspor jagung Amerika Serikat tahun $\mathrm{t}$ (ton)

$\mathrm{E}_{\mathrm{jASt}-1}=$ Ekspor jagung Amerika Serikat t-1 (ton)

$\mathrm{ER}=$ Nilai tukar rupiah $(\mathrm{Rp} / \mathrm{US} \$)$

ERJ $_{\mathrm{t}}=$ Nilai tukar Jepang terhadap dollar tahun $\mathrm{t}($ Yen/US\$)

ERJ $_{\mathrm{t}-1}=$ Nilai tukar Jepang terhadap dollar tahun $\mathrm{t}-1$ (Yen/US\$)

ERKS $_{\mathrm{t}}=$ Nilai tukar riil Korea Selatan terhadap dollar pada tahun $\mathrm{t}$ (Won/US\$)

EJW $_{\mathrm{t}}=$ Ekpor jagung dunia tahun $\mathrm{t}$ (ton)

$\mathrm{EJW}_{\mathrm{t}-1}=$ Ekspor jagung dunia tahun $\mathrm{t}-1$ (ton) 
HPP = Harga pembelian pemerintah $(\mathrm{Rp} / \mathrm{kg})$

$\mathrm{i}=$ tingkat suku bunga $(\%)$

ln $\quad=$ tingkat pendapatan (Rp)

$\mathrm{Lj} \quad=$ Luas areal panen jagung (ha)

$\mathrm{Mj} \quad$ = impor jagung Indonesia (ton)

$\mathrm{M}_{\mathrm{jjt}} \quad=$ Impor jagung Jepang tahun $\mathrm{t}$ (ton)

$\mathrm{M}_{\mathrm{j} \mathrm{t}-1}=$ Impor jagung Indonesia tahun sebelumnya (ton)

$\mathrm{M}_{\mathrm{jkst}}=$ Impor jagung Korea Selatan tahun $\mathrm{t}$ (ton)

$\mathrm{MJW}_{\mathrm{t}}=$ Impor jagung dunia tahun $\mathrm{t}$ (ton)

$\mathrm{MJW}_{\mathrm{t}-1}=$ Impor jagung dunia tahun $\mathrm{t}-1$ (ton)

Nrp = Nominal rate of protection

$\mathrm{P}_{\text {bit }} \quad=$ harga bibit jagung $(\mathrm{Rp} / \mathrm{kg})$

$\mathrm{P}_{\text {puk }} \quad=$ harga pupuk $(\mathrm{Rp} / \mathrm{kg})$

$\mathrm{P}_{\mathrm{k}} \quad=$ harga kacang tanah $(\mathrm{Rp} / \mathrm{kg})$

$\mathrm{P}_{\mathrm{p}} \quad=$ harga padi $(\mathrm{Rp} / \mathrm{kg})$

$\mathrm{P}_{\mathrm{dj}} \quad=$ harga jagung domestik $(\mathrm{Rp} / \mathrm{kg})$

$P_{w j}-P_{d j}=$ Harga jagung dunia dan harga jagung domestik $(\mathrm{Rp} / \mathrm{kg})$

Pop = populasi penduduk (jiwa)

$\mathrm{P}_{\mathrm{wj}} \quad=$ Harga jagung dunia (US\$/ton)

$\mathrm{P}_{\mathrm{djt}-1}=$ Harga jagung domestik tahun sebelumnya $(\mathrm{Rp} / \mathrm{kg})$

$\mathrm{P}_{\mathrm{wjt}-1}=$ Harga riil jagung dunia $\mathrm{t}-1$ (US\$/ton)

$\mathrm{P}_{\mathrm{wjt}}=$ Harga riil jagung dunia tahun $\mathrm{t}(\mathrm{US} \$ /$ ton)

$\mathrm{P}_{\text {wjt-1 }}=$ Harga jagung dunia pada tahun $\mathrm{t}-1$ (US\$/ton)

Qj = Produksi jagung (ton)

Qs = supply jagung Indonesia (ton)

Qj = produksi jagung Indonesia (ton)

Qd = Permintaan jagung domestik (ton)

$\mathrm{Q}_{\mathrm{jASt}-1}=$ produksi jagung Amerika Serikat $\mathrm{t}-1$ (ton)

$\mathrm{Qd}_{\mathrm{t}-1}=$ permintaan jagung tahun sebelumnya (ton)

$\mathrm{Q}_{\mathrm{jAGt}} \quad=$ Produksi jagung Argentina tahun $\mathrm{t}$ (ton)

$\mathrm{ST}_{\mathrm{jjt}} \quad=$ Stok Jagung Jepang tahun $\mathrm{t}$ (ton)

$\mathrm{ST}_{\mathrm{jkst}}=$ Stok jagung Korea Selatan tahun $\mathrm{t}(\mathrm{ton})$

$\mathrm{TW}_{\mathrm{t}} \quad=$ Tren waktu

$\mathrm{W} \quad=$ tingkat upah $(\mathrm{Rp})$

$\mathrm{Yj} \quad=$ Produktivitas jagung (ton/ha)

Pengujian model dilakukan dengan uji $\mathrm{F}$ dan koefisien determinasi $\left(R^{2}\right)$. Pengujian penduga parameter dilakukan dengan uji t.

Tujuan 2: Analisis Hasil Simulasi Kebijakan Tarif Jagung Terhadap Kinerja Ekonomi Jagung di Indonesia.

Simulasi dilakukan dengan menggunakan peramalan historis yaitu pada tahun 1990-2010. Simulasi yang dipakai yaitu: 1) Indonesia memberlakukan kebijakan tarif impor jagung dan pemerintah Indonesia menghilangkan tarif impor jagung $\left(T_{t}=0\right)$. Pada skenario ini kebijakan tanpa tarif impor jagung dimulai sejak Indonesia mengikuti kerjasama pada kawasan perdagangan bebas ASEAN yang dikenal dengan ASEAN Free Trade Area (AFTA). Isi kebijakan yang tertuang dalam AFTA diantaranya adalah penurunan tarif hingga menjadi nol sampai lima persen, penghapusan kuantitatif dan hambatanhambatan non tarif lainnya; dan 2) Melakukan perubahan pada tarif impor jagung (T) yaitu dengan menaikkan tarif impor jagung sebesar 5\% dan $10 \%$.

\section{Hasil dan Pembahasan}

1. Analisis Faktor-faktor yang Mempengaruhi Kinerja Ekonomi Jagung di Indonesia.

\section{a. Persamaan Produktivitas Jagung}

Berdasarkan hasil yang diperoleh, nilai $\mathrm{R}^{2}$ sebesar 0,954 yang berarti bahwa 95,4\% produktivitas jagung dipengaruhi oleh luas areal jagung, harga bibit jagung, harga pupuk jagung, tingkat upah dan suku bunga sedangkan sisanya sebesar 4,6\% dipengaruhi oleh faktor lain yang tidak terdapat dalam persamaan dengan taraf signifikansi sebesar 100\%. Berdasarkan Tabel 1. dapat diketahui bahwa variabel yang berpengaruh secara signifikan terhadap produktivitas jagung adalah luas areal jagung, harga pupuk dan suku bunga. Secara statistik, luas areal, harga pupuk dan suku bunga memiliki tingkat signifikansi yang lebih dari $85 \%$ sehingga dapat dikatakan berpengaruh secara signifikan terhadap produktivitas jagung.

Tabel 1. Faktor-faktor yang Berpengaruh Terhadap Produktivitas Jagung

\begin{tabular}{|c|c|c|c|}
\hline Variabel & $\begin{array}{l}\text { Parameter } \\
\text { Penduga }\end{array}$ & $\begin{array}{l}\text { t- } \\
\text { hitung }\end{array}$ & $\begin{array}{l}\text { Signifi- } \\
\text { kansi }\end{array}$ \\
\hline Intersept & 0,509 & 0,875 & 0,397 \\
\hline $\begin{array}{lr}\text { Luas } & \text { areal } \\
\text { panen } & \text { jagung } \\
(\mathrm{Lj}) & \end{array}$ & $6,267 \mathrm{E}-7$ & 4,418 & 0,001 \\
\hline $\begin{array}{l}\text { Harga bibit } \\
\text { jagung }\left(\mathrm{P}_{\mathrm{bit}}\right)\end{array}$ & $-3,255 \mathrm{E}-6$ & $-0,753$ & 0,464 \\
\hline $\begin{array}{l}\text { Harga pupuk } \\
\left(\mathrm{P}_{\mathrm{puk}}\right)\end{array}$ & 0,001 & 7,039 & 0,000 \\
\hline $\begin{array}{l}\text { Tingkat upah } \\
\text { (W) }\end{array}$ & 5,287 & 0,932 & 0,367 \\
\hline Suku bunga (i) & $-0,028$ & $-2,715$ & 0,017 \\
\hline \multicolumn{2}{|c|}{$\begin{array}{l}\text { R Square }=0,954 \\
\text { Signifikansi }=0,000\end{array}$} & \multicolumn{2}{|c|}{ F-Statistic $=57,784$} \\
\hline
\end{tabular}

b. Persamaan Luas Areal Jagung di Indonesia 
Berdasarkan hasil yang diperoleh, nilai $\mathrm{R}^{2}$ sebesar 0,809 yang berarti bahwa $80,9 \%$ luas areal jagung dipengaruhi oleh harga kacang tanah, harga padi, harga jagung, suku bunga, harga bibit jagung dan harga pupuk jagung sedangkan sisanya sebesar $19,1 \%$ dipengaruhi oleh faktor lain yang tidak terdapat dalam persamaan dengan taraf signifikansi sebesar $98,4 \%$. Tabel 2. menunjukkan bahwa variabel yang berpengaruh secara signifikan terhadap luas areal jagung adalah harga pupuk jagung.

Tabel 2. Faktor-faktor yang Berpengaruh Terhadap Luas Areal Jagung

\begin{tabular}{|c|c|c|c|}
\hline Variabel & $\begin{array}{l}\text { Parameter } \\
\text { Penduga }\end{array}$ & $\begin{array}{l}\text { t- } \\
\text { hitung }\end{array}$ & $\begin{array}{l}\text { Signifi } \\
\text {-kansi }\end{array}$ \\
\hline Intersept & 3093274,165 & 7,359 & 0,000 \\
\hline Harga & 241,099 & 1,157 & 0,268 \\
\hline \multicolumn{4}{|l|}{$\begin{array}{l}\text { kacang tanah } \\
\left(\mathrm{P}_{\mathrm{k}}\right)\end{array}$} \\
\hline $\begin{array}{l}\text { Harga padi } \\
\left(\mathrm{P}_{\mathrm{p}}\right)\end{array}$ & 209,432 & 0,708 & 0,491 \\
\hline $\begin{array}{l}\text { Harga jagung } \\
\text { domestik } \\
\left(\mathrm{P}_{\mathrm{dj}}\right)\end{array}$ & 196,155 & 1,032 & 0,491 \\
\hline $\begin{array}{l}\text { Suku bunga } \\
\text { (i) }\end{array}$ & 978,175 & 0,060 & 0,953 \\
\hline $\begin{array}{l}\text { Harga bibit } \\
\text { jagung }\left(\mathrm{P}_{\mathrm{bit}}\right)\end{array}$ & $-1,303$ & $-0,210$ & 0,837 \\
\hline $\begin{array}{l}\text { Harga pupuk } \\
\text { Jagung }\left(\mathrm{P}_{\text {puk }}\right)\end{array}$ & $-1217,908$ & $-2,138$ & 0,052 \\
\hline \multicolumn{2}{|l|}{ R Square $=0,8$} & \multicolumn{2}{|c|}{ F-Statistic $=4,101$} \\
\hline
\end{tabular}

c. Persamaan Impor Jagung di Indonesia

Tabel 3. Faktor-faktor yang Berpengaruh Terhadap Impor Jagung Indonesia

\begin{tabular}{llll}
\hline Variabel & $\begin{array}{l}\text { Parameter } \\
\text { Penduga }\end{array}$ & $\begin{array}{l}\mathrm{t}- \\
\text { hitung }\end{array}$ & $\begin{array}{l}\text { Signifi } \\
\text {-kansi }\end{array}$ \\
\hline $\begin{array}{l}\text { Intersept } \\
\text { Harga jagung } \\
\text { dunia }\left(\mathrm{P}_{\mathrm{wj}}\right)\end{array}$ & $-421423,448$ & $-2,023$ & 0,061 \\
Nilai tukar & 9,569 & $-2,616$ & 0,019 \\
rupiah (ER) & &,- 379 & 0,710 \\
$\begin{array}{l}\text { Permintaan } \\
\text { jagung } \\
\text { domestik (Qd) }\end{array}$ & 0,133 & 2,556 & 0,022 \\
$\begin{array}{l}\text { Impor jagung } \\
\begin{array}{l}\text { Indonesia } \\
\text { tahun }\end{array}\end{array}$ & $-0,018$ & $-0,382$ & 0,708 \\
$\begin{array}{l}\text { sebelumnya } \\
\left(\mathrm{M}_{\mathrm{jt}-1}\right)\end{array}$ & & \\
\hline $\begin{array}{l}\mathrm{R} \text { Square }=0,973 \\
\text { Signifikansi }=0,000\end{array}$ & & \\
\hline
\end{tabular}

Berdasarkan Tabel 3. diperoleh nilai $\mathrm{R}^{2}$ sebesar 0,973 yang berarti bahwa sebesar $97,3 \%$ impor jagung di Indonesia dipengaruhi oleh harga jagung dunia, nilai tukar rupiah terhadap dollar, permintaan jagung dan impor jagung tahun sebelumnya, sedangkan sisanya sebesar 2,7\% dijelaskan oleh faktor lain diluar persamaan dengan taraf kepercayaan sebesar $100 \%$. Tabel 3. menunjukkan bahwa variabel yang berpengaruh secara signifikan terhadap impor jagung Indonesia adalah harga jagung dunia dan permintaan jagung.

d. Persamaan Permintaan Jagung

Tabel 4. Faktor-faktor yang Berpengaruh Terhadap Permintaan Jagung di Indonesia

\begin{tabular}{llll}
\hline Variabel & $\begin{array}{l}\text { Parameter } \\
\text { Penduga }\end{array}$ & t-hitung & $\begin{array}{l}\text { Signifi } \\
\text {-kansi }\end{array}$ \\
\hline $\begin{array}{l}\text { Intersept } \\
\text { Harga jagung } \\
\text { domestik }\end{array}$ & $\begin{array}{l}7435988,304 \\
\text { 550,351 }\end{array}$ & 3,619 & 0,003 \\
$\left(\mathrm{P}_{\mathrm{dj}}\right)$ & 1,181 & 0,256 \\
$\begin{array}{l}\text { Populasi } \\
\text { (Pop) }\end{array}$ & $-0,017$ & $-2,582$ & 0,021 \\
$\begin{array}{l}\text { Tingkat } \\
\text { pendapatan } \\
(\text { ln) }\end{array}$ & 0,677 & 2,263 & 0,039 \\
$\begin{array}{l}\text { Permintaan } \\
\text { jagung tahun }\end{array}$ & 0,497 & 3,426 & 0,004 \\
$\begin{array}{l}\text { sebelumnya } \\
(\text { Qd }\end{array}$ & & & \\
\hline $\begin{array}{l}\text { R Square }=0,989 \\
\text { Signifikansi }=0,000\end{array}$ & F-Statistic $=325,599$ \\
\hline
\end{tabular}

Berdasarkan Tabel 4. dapat diketahui bahwa nilai $\mathrm{R}^{2}$ dari persamaan permintaan jagung sebesar 0,989. Hal ini berarti bahwa sebesar $98,9 \%$ permintaan jagung di Indonesia dipengaruhi oleh harga jagung, populasi, tingkat pendapatan dan permintaan jagung tahun sebelumnya dengan signifikansi sebesar $100 \%$. Variabel yang berpengaruh secara signifikan terhadap permintaan jagung di Indonesia adalah tingkat populasi, tingkat pendapatan dan permintaan jagung tahun sebelumnya.

\section{e. Persamaan Harga Jagung Indonesia}

Berdasarkan Tabel 5. dapat diketahui bahwa nilai $R^{2}$ sebesar 0,990 yang berarti bahwa sebesar 99\% harga jagung domestik dipengaruhi oleh harga jagung dunia, nilai tukar rupiah terhadap dollar, nominal rate of protection, harga 
pembelian pemerintah dan harga jagung tahun sebelumnya.

Tabel 5. Faktor-faktor yang Berpengaruh Terhadap Harga Jagung Indonesia

\begin{tabular}{|c|c|c|c|}
\hline Variabel & $\begin{array}{l}\text { Parameter } \\
\text { Penduga }\end{array}$ & t-hitung & $\begin{array}{l}\text { Signifi } \\
\text {-kansi }\end{array}$ \\
\hline Intersept & $-915,055$ & $-3,766$ & 0,002 \\
\hline $\begin{array}{l}\text { Harga jagung } \\
\text { dunia }\left(\mathrm{P}_{\mathrm{wj}}\right)\end{array}$ & 7,574 & 3,784 & 0,002 \\
\hline $\begin{array}{l}\text { Nilai tukar } \\
\text { rupiah (ER) }\end{array}$ & 0,053 & 2,367 & 0,033 \\
\hline $\begin{array}{l}\text { Nominal } \\
\text { Rate of } \\
\text { Protection } \\
\text { (Nrp) }\end{array}$ & $-48,032$ & $-2,159$ & 0,049 \\
\hline $\begin{array}{l}\text { Harga } \\
\text { pembelian } \\
\text { pemerintah } \\
\text { (HPP) }\end{array}$ & 0,122 & 0,625 & 0,542 \\
\hline $\begin{array}{l}\text { Harga jagung } \\
\text { domestik } \\
\text { tahun } \\
\text { sebelumnya } \\
\left(\mathrm{P}_{\mathrm{djt}-1}\right)\end{array}$ & 0,898 & 6,764 & 0,000 \\
\hline $\begin{array}{l}\text { R Square }=0,9 \\
\text { Signifikansi }=\end{array}$ & & F-Statisti & 278,017 \\
\hline
\end{tabular}

Hasil ini juga menunjukkan bahwa pengaruh secara keseluruhan ini berada pada taraf kepercayaan sebesar $100 \%$. Tabel 5 menunjukkan bahwa variabel yang berpengaruh secara signifikan terhadap harga jagung domestik antara lain harga jagung dunia, nilai tukar rupiah, nominal rate of protection dan harga jagung tahun sebelumnya.

2. Analisis Simulasi Kebijakan Tarif Impor Jagung Terhadap Kinerja Ekonomi Jagung di Indonesia

Berdasarkan Tabel 6. dapat diketahui bahwa penghapusan tarif impor berdampak pada penurunan harga jagung domestik yang berdampak juga pada penurunan produksi jagung domestik dengan produktivitas dan luas areal lahan jagung juga turun. Sedangkan penghapusan tarif impor menyebabkan kenaikan pada impor jagung Indonesia. Karena harga jagung domestik yang turun menyebabkan permintaan dalam domestik menjadi naik pada kondisi tarif $0 \%$. Tarif impor jagung sebesar 5\% dan $10 \%$ menyebabkan harga jagung domestik lebih tinggi dibandingkan dengan tidak adanya tarif. Pengenaan tarif sebesar 5\% juga berdampak pada peningkatan produksi, produktivitas dan luas areal jagung dibandingkan dengan tidak adanya tarif impor jagung. Sedangkan untuk impor jagung Indonesia lebih rendah dibandingkan dengan penghapusan tarif impor jagung.

Tabel 6. Rekapitulasi Hasil Simulasi Tarif Impor Jagung Terhadap Kinerja Ekonomi Jagung di Indonesia

\begin{tabular}{clllll}
\hline No. & \multicolumn{1}{c}{ Variabel Endogen } & \multicolumn{1}{c}{ T=T } & \multicolumn{1}{c}{$\mathbf{T}=\mathbf{0 \%}$} & \multicolumn{1}{c}{ T naik 5\% } & \multicolumn{1}{c}{ T naik 10\% } \\
\hline 1. & Produktivitas Jagung $(\mathrm{Yj})$ & 3.508 .335 & 3.305 .236 & 3.457 .931 & 3.487 .568 \\
2. & Luas Areal Panen Jagung $(\mathrm{Lj})$ & 3,223 & 3,056 & 3,111 & 3,156 \\
3. & Harga Jagung Domestik $\left(\mathrm{P}_{\mathrm{dj}}\right)$ & 1645,579 & 1644,529 & 1645,931 & 1646,083 \\
4. & Permintaan Jagung Domestik & 11.429 .875 & 11.462 .375 & 11.422 .875 & $11.421 .537,75$ \\
5. & Impor Jagung Indonesia $(\mathrm{Mj})$ & $1.451 .112,7$ & $1.466 .112,7$ & $1.448 .612,6$ & $1.441 .112,7$ \\
6. & Produksi Jagung Indonesia $(\mathrm{Qj})$ & 12.880 .988 & 12.780 .988 & 12.881 .222 & 12.931 .092 \\
\hline
\end{tabular}

\section{Kesimpulan}

Faktor-faktor yang berpengaruh terhadap kinerja ekonomi jagung antara lain:

a. Produktivitas jagung secara signifikan dipengaruhi oleh luas areal jagung, harga pupuk jagung dan tingkat suku bunga.

b. Luas areal jagung secara signifikan dipengaruhi oleh harga kacang tanah dan harga pupuk jagung.

c. Impor jagung Indonesia secara signifikan dipengaruhi oleh harga jagung dunia dan permintaan jagung domestik. d. Permintaan jagung secara signifikan dipengaruhi oleh populasi, tingkat pendapatan dan permintaan jagung tahun sebelumnya.

e. Harga jagung domestik secara signifikan dipengaruhi oleh harga jagung dunia, nilai tukar rupiah, nominal rate of protection dan harga jagung tahun sebelumnya.

Hasil simulasi perubahan tarif impor jagung berdampak sebagai berikut:

a. Penghapusan tarif impor jagung berdampak pada penurunan harga jagung domestik, peningkatan permintaan jagung 
serta meningkatkan impor jagung Indonesia, namun penghapusan tarif berdampak pada penurunan produksi jagung nasional.

b. Peningkatan tarif impor jagung sebesar 5\% dan $10 \%$ berdampak pada peningkatan harga jagung domestik, penurunan permintaan jagung domestik, menurunkan impor jagung Indonesia dan relatif meningkatkan produksi jagung Indonesia.

\section{Daftar Pustaka}

[1]. Anindita, R. 2008. Bisnis dan Perdagangan Internasional. Penerbit Andi. Yogyakarta.

[2]. Anindita, R. 2008. Pendekatan Ekonomi Untuk Analisis Harga. Prenada Media Group. Jakarta.

[3]. Apridar. 2009. Ekonomi Internasional. Graha Ilmu. Yogyakarta.

[4]. Ariani, M. dan Ashari. 2003. Arah, Kendala dan Pentingnya Diversifikasi Konsumsi Pangan di Indonesia. Forum Agro Ekonomi. Vol. 21, No. 2.Bogor.

[5]. BPS. (2012). Produksi Jagung Nasional. Badan Pusat Statistik. Jakarta.

[6]. Darsono. 2009. Analisis Dampak Pengenaan Tarif Impor Kedelai bagi Kesejahteraan Masyarakat. Jurnal Imuilmu Pertanian, 5 (1): 1-21.

[7]. Fathorrazi, M. dan Tati S. J. 2012. Teori Ekonomi Mikro. Graha Ilmu. Yogyakarta.

[8]. Kementerian Pertanian. 2011. Neraca Bahan Makanan Indonesia. Kementerian Pertanian, Jakarta.

[9]. Krugman, P. R. dan Maurice, Ostefeld. 1999. Ekonomi Internasional: Teori dan Kebijakan. PT. Raja Grafindo Persada. Jakarta.

[10]. Semaoen, I. 2011. Mikroekonomi Intermediate. UB Press. Malang.

[11]. Timor, S. D. 2008. Analisis Faktor-faktor yang Mempengaruhi Produksi dan Impor jagung Di Indonesia. Bogor: Institut pertanian Bogor. 